\title{
The 1931 London Congress: The Rise of British Marxism and the Interdependencies of Society, Nature and Technology
}

\author{
Gerardo Ienna \\ Ca’ Foscari University of Venice, Italy \\ gerardo.ienna@unive.it
}

Giulia Rispoli

Max Planck Institute for the History of Science (MPIWG), Germany

grispoli@mpiwg-berlin.mpg.de

\begin{abstract}
The Second International Conference of the History of Science, Technology, and Medicine, held in London in 1931, exerted a profound influence on the historiography of science, giving rise to a new research field in the anglophone world at the intersection of social and political studies and the history of science and technology. In particular, Boris Hessen's presentation on the Social and Economic Roots of Newton's Principia successfully ushered in a new tradition in the historiography of science. This article introduces and discusses the London conference as a benchmark in the history of the social study of science within a Marxist and materialist tradition. In contemporary science and technology studies, political epistemology, and the study of society-nature interaction, it is no less relevant today than it was at the beginning of the fabulous 1930s. In reconstructing some important theses presented by the Soviet delegation in London, we aim to revive the conference's legacy and the approach promoted on that occasion as a pretext to address current debates about society's major transition toward a new agency and ways of existence in the Earth system. In particular, the London conference invited us to think of the growing metabolic rift between society, technology, and nature, and further reflects a historical moment of profound environmental and political crisis.
\end{abstract}

Keywords: Soviet Marxism in science; Bernalism; Naukovedenie; Anthropocene; society-nature interaction 


\section{The beginnings of the Social Study of Science in the 1930s}

How should society advance in the future? How will human development flourish and what sort of human progress do we need in order to solve the crisis of capitalism both in economic and cultural terms?

It seems that addressing these questions was the primary objective of the Soviet delegation at the Second International Congress of the History of Science, held in London in 1931. Led by the party leader and Pravda editorialist, Nikolay Bukharin, the Soviet delegation introduced the union's achievements in science and technology to a group of mostly leftist Western scientists and intellectuals in the framework of a Special Session titled Science at Crossroads. ${ }^{1}$ The Soviet participants also expressed their general concern that capitalism was molding the way in which science and its progressive division into several sub-disciplines was developing and consequently proposed alternative paths that were being implemented in Russia.

One of the most animating debates in London concerned a unifying approach and epistemic vision to guide the role of science, technology, and its application within society. Theory and praxis under capitalism, the Soviets lamented, were becoming too distant and unrelated to each other despite the historic integration of the two. They claimed that an appropriate analysis of the history of science and technology should incorporate aspects that had been considered secondary until then, namely, the social, cultural, historical, economic, and therefore political elements, which the Soviets argued were inextricably linked with scientific fabric and production. ${ }^{2}$

Among the members of the Soviet delegation, the presentation by Boris Hessen became the guiding light for a new foundational trajectory in the historiography of science. Only three years after his participation at the London conference, the Soviet physicist was accused of infidelity toward orthodox Marxism and became a victim of Stalin's purge in 1934. His endorsement of general relativity and particularly quantum mechanics as well as his theoretical proximity to the physicist Ernst Mach, considered as reactionary representative of bourgeois science and thus antithetical to the principles of Marxism, caused him to be condemned and executed. ${ }^{3}$

\footnotetext{
1 Nikolay Bukharin, ed., Science at the crossroads. Papers presented to the International Congress of the History of Science and Technology Held in London from June 29th to July 3rd, 1931, by the Delegates of the USSR (London: Kniga, 1931); Nikolay Bukharin, ed., Science at the Cross Roads. Papers presented to the International Congress of the History of Science and Technology (London: Frank Cass \& Co. Ltd., 1971); Nikolay Bukharin, ed., Scienza al bivio. Interventi dei delegati sovietici al II Congresso Internazionale di Storia della Scienza e della Tecnologia (Bari: Di Donato 1977).

${ }^{2}$ Gary Werskey, The Visible College. The Collective Biography of British Scientific Socialists in the 1930s (New York: Holt Rinehart Winston, 1979).

3 On Boris Hessen's life and work see also Loren Graham, "The Socio-Political Roots of Boris Hessen: Soviet Marxism and the History of Science," Social Studies of Science 15, no. 4 (1985): 70522; Pablo Huerga-Melcón, La ciencia en la encrucijada (Oviedo: Pentalfa Ediciones, 1999); Pietro D.
} 
The presentation by Hessen at the London congress, titled The Social and Economic Roots of Newton's Principia, was a lucid and captivating Marxist exposition of Newtonian mechanics. ${ }^{4}$ His description and analysis of Newton's scientific thinking and system of values tried to account for the material bases of scientific research and planning that characterized Newton's time and context. ${ }^{5}$ Hessen highlighted how Newton's ideas were intrinsically rooted in the political and economic environment of seventeenth-century England. Principia indeed exhibits the needs that arose in the new industrial setting for the nascent political class, including mechanical and technical problems related to production, trade, maritime navigation, and war. These areas, in turn, reflected the state of the natural sciences at the time.

The technical problems of the seventeenth century, as Hessen points out, not only shaped the development of physical science, but were essentially triggered by problems faced by the bourgeoisie in its effort to establish itself as a ruling class. In this sense, Hessen lucidly and elegantly showed how scientific progress was connected to the acquisition of political and economic power and vice-versa.

It is no surprise that the central part of Principia discusses the expansion of communication routes by land and sea, mining technologies, metallurgy, and of course, the military industry. These preoccupations derived from the emergence of the new economic system based on mercantile capital and manufacture, therefore arising from the ashes of feudalism. The state of the art in the natural sciences manifested the economic transition to capitalism. Newton himself, according to Hessen, can be regarded as a typical representative of the rising bourgeoisie and expressed all of the traits that characterized his social class.

As Loren Graham points out, Hessen defended both a Marxist view of science, expressed in the association between scientific theories and their material and economic substratum, as well as modern physics in its more internal, theoretical aspects. ${ }^{6} \mathrm{He}$ did so in the 1930 s, at a time when Marxist intellectuals had declared the irreconcilability of the two dimensions, opting for a reductionist materialism that understands science as the deterministic product of forces of economic production. As previously mentioned, Hessen did not defend socio-economic determinism. His ideas about the relationship between structure and superstructure resembles

Omodeo, "L'eredità di Boris Hessen: per un approccio socio-politico alla scienza in età moderna," in Boris Hessen, Le radici sociali ed economiche della meccanica di Newton, ed. Gerardo Ienna, 119-50 (Rome: Castelvecchi, 2017).

${ }^{4}$ Gideon Freudenthal and Peter McLaughlin, ed., The Social and Economic Roots of the Scientific Revolution: Texts by Boris Hessen and Henryk Grossmann (Dordrecht: Springer, 2009).

5 Gerardo Ienna and Giulia Rispoli, "Boris Hessen at the Crossroads of Science and Ideology," Society and Politics, 13, no. 1 (2019): 37-63.

${ }^{6}$ Graham, "The Socio-Political Roots of Boris Hessen," 1985. See also Maria Paula Diogo, "The Perfect Pair: Bloch, Febvre, and the History of Science and Technology," HoST - Journal of History of Science and Technology 14, no. 2 (2020): 73-93. 
a theory of equilibrium in which both base and superstructure influence each other in a coevolutionary fashion.

In his introductory lecture, which was meant to set the tone and the philosophical approach underlying the Soviet vision of the history of science and technology, Bukharin used the theory of equilibrium as an epistemological device to attest the balancing, complementary relationship between theory and praxis. ${ }^{7}$ He noted that both theory and praxis are social activities that can be seen as a condensed social practice. ${ }^{8}$ The division between intellectual and physical labor has generated an enduring contradiction according to which the production of ideas is completely different, and of a different nature, than the concrete production of objects. ${ }^{9}$

Bukharin quotes the Russian biogeochemist Vladimir Vernadsky to underscore the point that in a world massively transformed by humanity, ideas and physical labor must be seen as inseparable activities that represent the two faces of the same coin. Since human society has entirely changed the face of the biosphere with the support and use of the most advanced theoretical and practical skills developed by mastering science and technology, a differentiation between what is purely cognitive and what is strictly practical is impossible to endorse. ${ }^{10}$ In particular Bukharin has in mind Vernadsky's theory of the noosphere, from the Greek term nous (mind), which expresses the idea that humanity has acted as the most powerful geological agent, transforming the biosphere into a new emerging entity characterized by the all-encompassing impact of human activities on the Earth's crust. The biosphere-noosphere theory recalls the theory of the Anthropocene, a notion explaining the Earth's transition into a new geological epoch different from the previous one, the Holocene, and characterized by the imprint of humanity on the Earth's ecology and geology. ${ }^{11}$ Similarly, Vernadsky's theory of the noosphere reveals that the empirical and theoretical generalization of the new state of the world is globally

\footnotetext{
7 Ilmari Susiluoto, The Origins and Development of Systems Thinking in the Soviet Union: Political and Philosophical Controversies from Bogdanov and Bukharin to Present-Day Reevaluations (Helsinki: Suomalainen tiedeakatemia, 1982); Constantine K. Skordoulis, "Bukharin and the Social Study of Science," Stud East Eur Thought 67 (2015): 75-89; James D. White, Red Hamlet, The Life and Ideas of Alexander Bogdanov (Amsterdam: Brill, 2018).

${ }^{8}$ Bukharin, Science at the Cross Roads, 13.

${ }^{9}$ It is worth mentioning here that Bukharin was one of the most eminent intellectuals who worked for the institutionalization of the history of science and knowledge as autonomous disciplinary fields that, at the same time, are fundamental to inform practical endeavors.

${ }^{10}$ About Vernadsky's biosphere-noosphere theory, see Vladimir I. Vernadsky, The Biosphere (Leningrad, 1926); Vladimir I. Vernadsky, The Biosphere (New York: Copernicus/Springer-Verlag, 1998); and Vladimir I. Vernadsky, Scientific Thought as a Planetary Phenomenon (Moscow: Nongovernmental Ecological V. I.Vernadsky Foundation, 1997).

${ }^{11}$ Paul Crutzen "Geology of Mankind," Nature 415 (2002): 23; Will Steffen, Jacques Grinevald, Paul Crutzen and John Mcneill, "The Anthropocene: Conceptual and Historical Perspectives," Philosophical Transactions of The Royal Society A Mathematical Physical and Engineering Sciences 369 (2011): 842-67. See also Alec Brooke and Elena Fratto, "Towards a Russian Literature of the Anthropocene," Russian Literature 114, no. 115 (2020): 1-22.
} 
transformed by science and technology. The state of the planet is indeed so different that it has no precedent in either geochemical or anthropological history, and this global change is due to the evolution of human science and technology oriented toward human expansion on the planet. Although they seem to have much in common, the two elaborations, the Anthropocene and the noosphere, are analogous only at first glance. The Anthropocene is primarily associated with societal and environmental collapse due to overexploitation of natural resources that is affecting the Earth's metabolism (the circulation and transformation of energy and materials through its different subsystems). Vernadsky's noosphere is a more hopeful concept. It includes an appeal to the human ability to reorient science and technology towards new rationality that would ultimately restore the existing fracture between humanity and nature. ${ }^{12}$ This fracture is similar to a metabolic rift, through which Marx would initially describe the destruction of the soil due to industrialized agriculture, which is emblematic of the profound disconnection between society and nature caused by division of labor and the dispossession of the means of production brought about by capitalism. ${ }^{13}$ Instead, the noosphere is invoked not only as a necessity to understand human agency on the biosphere, but also as an exhortation to re-establish the relationship between human systems and the environment and, to this aim, reclaim and reorganize scientific work and research. ${ }^{14}$

Inspired by Vernadsky, Bukharin concludes that, in a certain sense, the world we live in is a concrete visible manifestation that any division between theory and praxis is obsolete and misleading. As he points out: "Living and working in the biosphere, social man has radically remolded the surface of the planet. The physical landscape is even more becoming the seat of some branch of industry and agriculture, and artificial material medium has filled space, gigantic success of technique and natural science confront us, the radius of cognition, with the progress of exact apparatus of measurement and new methods of research has grown extremely wide."And all this, he continues, is unthinkable without real knowledge. ${ }^{15}$

This co-evolution of humans with the biosphere that has been mediated by the resourceful employment of technologies prompts us to consider humanity as a technological historical subject. ${ }^{16}$ Nature and society develop as one single historical entity where human knowledge is

12 Clive Hamilton and Jacques Grinevald, "Was the Anthropocene anticipated?," The Anthropocene Review 1, no. 2 (2015): 1-14; Giulia Rispoli, "Genealogies of Earth System Thinking," Nature Reviews Earth \& Environment 1 (2020): 4-5; Jacques Grinevald and Giulia Rispoli, "Vladimir Vernadsky and the Co-Evolution of the Biosphere, the Noosphere and the Technosphere," Technosphere Magazine, June 20, 2018: 1-9.

${ }^{13}$ John Bellamy Foster, The Return of Nature. Socialism and Ecology (New York: Monthly Review Press, 2020).

${ }^{14}$ Vladimir I. Vernakdsy, Izbrannye trudy po istorii nauki (Moscow: Nauka, 1981).

15 Emphasis of the authors. Bukharin, Science at the Cross Roads, 17.

${ }^{16}$ Christoph Rosol, Sara Nelson and Jürgen Renn, "In the machine room of the Anthropocene," The Anthropocene Review 4, no. 1 (2017): 2-8. 
a practical actor that also manifests itself through technologies. As practice influences forms of cognition, cognition influences forms and modes of production in a recursive way.

Scientific theories developed in capitalist systems are responsible for two mistakes, according to Bukharin: the first mistake is treating practice as an isolated component that can transcend the social, material, and economic world. The second mistake is treating praxis as something alien to cognitive and symbolic systems. To overcome this contradiction, Bukharin returns to the theory of equilibrium, and in doing so he draws on Alexander Bogdanov's concept of tektological organization for which every whole is a system of activities, unfolding in a particular environment and in constant interaction with it. ${ }^{17}$ Bogdanov's vision of the relations between theory and praxis greatly inspired Bukharin, who considered him one of the most erudite theoreticians of those years promoting a vision of science in dialogue not only with the economic aspects of society but also with symbolic, cognitive, spiritual, and linguistic aspects. Thus, according to Bogdanov, society is a system of human activities in the natural environment and in a process of struggle against its resistances. ${ }^{18}$ In this respect, Bukharin points out that science derives from the continuous effort of sharpening human experiences in a shared working environment, with the ultimate goal of serving humanity's orientation in the world. Likewise, in an article entitled Sotzalism Nauki (The Socialism of Science) about the social role of science and the need for scientific-technological education of the masses, Bogdanov defined science as an instrument of the social organization of work. In fact, the expression "struggle with nature," used by Bogdanov in his Tektology $y^{19}$ and by Bukharin in London, is not a call for human intervention in modifying nature at the expense of the latter-as we now witness with the unprecedented risks that human activity imposes to other species and to humanity as well. Struggle for life is not an endorsement of nature exploitation. Bogdanov uses the term "struggle" to explain that society adapts to the natural environment through labor. Social labor is interpreted as means of production directed towards the external nature. The means of production in turn are meant as technological adaptations, which have the immediate effects of changing nature. Therefore, the struggle with external nature serves to

17 As White pointed out quoting Bukharin's eulogy given at his funeral, "Bogdanov was without doubt one of the greatest and most original thinkers of our time and should occupy a prominent place in the modern history of Russia and the history of European Marxism, but because he fell foul of Lenin, the role he played in the Russian revolutionary movement and his contribution to the various spheres of knowledge in which he was involved, have been deliberately obscured." See White Red Hamlet, XI. An English version of Bukharin's speech at Bogdanov's funeral translated by Evgeny Pavlov, is available here: https://platypus1917.org/2013/06/01/bukharin-on-bogdanov/ On Bukharin and Bogdanov see White, Red Hamlet; Susiluoto, The Origins and Development of Systems.

${ }_{18}$ On nature and social agency from the point of view of historical materialism, see Andreas Malm, The Progress of this Storm, Nature and Society in a Warming World (London: Verso Book, 2017).

19 Alexander A. Bogdanov, Essays in Tektology, the general science of organization (London: Intersystem Publication, 1984); Alexander A. Bogdanov, Bogdanov's Tektology, Book 1 (Hull: Centre for Systems Studies, University of Hull, 1996). 
highlight the active involvement of society in their material world, as it occurred at any stage of biological development and evolution and in human society through labor. Indeed, following Marx, Bogdanov believes that society is part of nature and thus subjected to its laws. ${ }^{20}$ It can even be argued that the struggle with nature reveals an attempt to restore that metabolic rift that separated society from nature (seen as an alienated entity molded by humans through agricultural and industrial production) under capitalism. ${ }^{21}$ In fact, it is worth remembering that Marx's concept of metabolic rift is closely related to the ownership of the means of production, which the proletariat has no longer direct access to. Struggling with nature, in this respect, would mean that the proletariat would re-obtain the means of production and re-establish a direct contact with nature.

Now, to revive the social and economic roots of science and technology, it is important to recover the link of labor with social and material contexts in historical perspective. In this respect, economist Modest Rubinstein, another Soviet participant in London, pointed out that even the most abstract form of scientific investigation has been possible only under the influence of specific technologies in a given context. These technologies, in turn, become more powerful as their application and function concerns new forms of production. In other words, scientific investigation becomes itself a sort of large-scale production organized to fulfil specific industrial plants that requires a large technical and administrative apparatus with laboratories, equipment, teams, a systematic agenda, and so forth. This scientific organization that has grown in scale and scope has the ultimate goal of sustaining and supporting the capitalist system and its industrial apparatus. ${ }^{22}$ Even when it seems abstract, neutral, and detached, science follows the scope of accommodating and growing its system in relation to the questions that capitalism poses to it, and tries to find solutions to problems that arise specifically within that (capitalist) society. The extension and inclusion in the science and technology discourse of different points of view that different sub-disciplines might bring in, is an answer to the requirements posed by industrial development.

${ }^{20}$ Alexander A. Bogdanov, Empiriomonism: Essays in Philosophy (Leiden \& Boston: Brill 2019); David J. Rowley, "The Influence of Friedrich Engels on Alexander's Bogdanov Basic Elements on the Historical View of Nature," Studies in East European Thought (2021); Giulia Rispoli, "Sharing in action. Bogdanov, the living experience and the systemic concept of the environment," in The Spherical Book, ed. Pia Tikka (Helsinki: Aalto University, 2015); Alexander A. Bogdanov, "Sotsializm Nauki" in Voprosy sotsializma: Raboty raznykh let (Moscow: Politizdat, 1990).

${ }^{21}$ Karl Marx, Capital, vol. III (New York: Vintage, 1981), 949; John Bellamy Foster, "Marx’s Theory of Metabolic Rift: Classical Foundations for Environmental Sociology," The American Journal of Sociology 105, no. 2 (1999): 366-405.

${ }^{22}$ Modest Rubinstein, "Relations of Science, Technology and Economics, Under Capitalism and in the Soviet Union," in Science at the Cross Roads, ed. N. Bukharin, 43-66 (London: Frank Cass \& Co. Ltd., 1971). 
In the 1930s, the idea of forging an economic system opposed to capitalism was still endorsed fiercely in those contexts where Marxist philosophy had a strong presence. As Rubinsten pointed out, the state of science and technology under capitalism had not yet reached a global dimension, therefore another approach to science was possible in socialist countries. Bukharin and Rubinstein argued for a transformation of science based on a Marxist elaboration of the relationship between nature and society. Restoring the rift between human agency and nature is a first step towards the noosphere, which is related to the possibility of humanity to acquire full awareness of the role and weight of science and technology in directing, with enormous consequences, the evolution of the biosphere. The most visible explanation of how humanity acted as an agent to transform the environment all around is offered by technologies developed in close relation with industrial development in a specific material setting. Already in the 1930s, Rubinstein identified a problem that is particularly stressed nowadays in the framework of the Anthropocene debate, that of the origins of inequalities that has been produced by uneven and unregulated access to natural resources perpetrated under a system—capitalismthat has worked by cheapening the price of commodities looted in some regions of the world to fuel the emerging European capitalist society. ${ }^{23}$ Capitalism has a colonial dimension rooted in the nineteenth century New Imperialism, which, in turn, is at the core of the process of industrialization and globalization. The Industrial Revolution, for example, entailed a global environmental transformation made possible thanks to raw materials, ores (such as copper), and other commodities (like cotton, also imported from other regions of the world), which fueled the European economic systems and contributed to establishing the supremacy of Great Britain. ${ }^{24}$

Rubinstein maintained that one of the most worrisome consequences of capitalism is the expropriation of resources, which is coupled with the enormous difficulties arising from their disposal. Capitalist society is a wasteful society, and accumulation, rather than rational consumption, is the principle beyond its functioning, which generates long periods of global crisis. Rubinstein pointed out that overproduction, congested markets, depressions and crises are features of capitalist societies and their furious tendency toward antagonisms. In fact, he continued, modern capitalism is raised by the development of monopolies that lead to the emergence of leading groups and lobbies of financial capital. This has been particularly clear

${ }^{23}$ Christophe Bonneuil and Jean-Baptiste Fressoz, The Shock of the Anthropocene. The Earth History and Us (London/New York: Verso book, 2016).

${ }^{24}$ Kenneth Pomeranz, The Great Divergence: China, Europe, and the Making of the Modern World Economy (Princeton: Princeton University Press, 2000); John McNeill, Something New Under the Sun: An environmental History of the Twentieth century (New York, London: Norton \& Company, 2000); Thomas Turnbull, "Energy, history, and the humanities: against a new determinism," History and Technology 37, no. 2 (2021); Chris Evans and Olivia Saunders, "A world of copper: Globalizing the Industrial Revolution, 1830-70," Journal of Global History 10, no. 1 (2015): 3-26. 
in the case of development of electrification in Western countries where antagonistic practices take the most visible shape. ${ }^{25}$

Rubinstein dedicated his second lecture at the London conference to the topic of Russia's plan for electrification, which is another extraordinary example of the importance of justifying and embedding scientific and technological achievements in the economic, productive, industrial texture of society. He mentions that "even more important than the planning of scientific research is the direct organizational connection of science and technology with the large masses of the working class." 26 This connection, Bernstein says, is now beginning to be realized in the Soviet Union where the workers are learning how to master science and technology. The Soviet electrification plan, GOELRO (State commission for the electrification of Russia), which began during the first years of Vladimir Lenin's presidency had a very important political dimension aimed at elevating communism. Despite this utterly propagandistic aspect, electrification was conceived as a popular, basic, and lucid plan that should present the perspective of the masses, socialist production, and labor. ${ }^{27}$ Electrification indeed gave an extraordinary boost to the country's technological development, and allowed further achievements in the most diverse areas of scientific activity, including education and research.

As we shall discuss in the next paragraph, the interest in and attention to science's role in society, which was the effect of the Soviet scientists' talks at the congress, would have a profound impact on a circle of active scientists in the United Kingdom, leaving a mark in the way science and technology will be deployed in support of social and political claim.

\section{The debates in the United Kingdom stemming from the London Congress}

During the congress and in the following days, the theses supported by the Soviet delegates generated a strong debate. Its resonance was broadly perceived by those present at the event in London. At the time, there was a very active circle of scientists in the United Kingdom engaged in political leftism, whom Werskey called the "visible college." 28 This group included John Desmond Bernal, John Haldane, Lancelot Hogben, ${ }^{29}$ Hyman Levy, and Joseph Needham. These authors had a common interest in the investigation of science's role in society. Excluding

${ }^{25}$ Rubinstein, Relations of Science, Technology and Economics, 113-45.

${ }^{26}$ Ibid., 61. Italics in the original text.

27 Ibid., 144.

28 The concept of the visible college was coined by Werskey, echoing the expression "invisible college," which was employed by Robert Boyle to refer to a dozen natural philosophers gathered around him in 1660. Gary Werskey, The Visible College. The Collective Biography of British Scientific Socialists in the 1930s (New York: Holt Rinehart Winston, 1979).

${ }^{29}$ He proposed the immediate publication of the texts of the Soviet delegation. 
Haldane, ${ }^{30}$ everybody in this group was at the 1931 congress and remained strongly influenced by the talks of the Soviet delegation.

The intervention of the Soviet delegation was immediately perceived as significant and, for this reason, it was decided on the first day of the conference (June 29) that the Soviet interventions should be published in English in a volume entitled Science at the Crossroads. During the course of the conference, a group of translators and proofreaders at the Russian Embassy worked hard to prepare the volume for print. On the morning of July 4, during the actual speech of the Soviet delegation, a first unbound version of the Soviet papers was distributed. The complete collection of the Soviet delegates' papers was published by the Russian Foreign-Language Press about ten days after the end of the conference. Despite numerous typographical errors and inaccurate linguistic revision of the translation, copies of the book quickly sold out. ${ }^{31}$ An expanded version (with revisions) introduced by Paul Gary Werskey and including a preface by Joseph Needham appeared in $1971 .{ }^{32}$

The Marxist approach proposed by these delegates clearly separated them from the positivist and Comtian approach to understanding the history of science. ${ }^{33}$ For a long time this discipline had, in fact, been practiced as a secondary activity by professional scientists who had often not deeply reflected on the theoretical-historical model implicit in their construction of historical narratives. During the very early stages of institutionalization, the history of science thus crystallized around the celebration of great personalities, such as Galileo Galilei, Johannes Kepler, and Isaac Newton, who were often presented as intellectual figures capable of bringing a radical transformation to the sphere of human knowledge through their genial contribution. However, this approach underestimated the role played by certain forms of knowledge and certain types of actors (therefore marginalized in standard narratives) in enabling the social emergence of scientific activity. The interventions of Bukharin, Hessen, Rubinstein, and others emphasized for the first time in the history of the historiography of science the role of technicians in the development of science, the impact of cultural-religious convictions on scientific practices, and particularly the determinations coming from the economic-social

\footnotetext{
${ }^{30}$ Haldane was the only one absent at the congress. He would only turn to Marxism after the Spanish Civil War in 1936.

${ }^{31}$ Gad Freudenthal and Peter McLaughlin, "Classical Marxist Historiography of Science: The HessenGrossmann-Thesis," in The Social and Economic Roots of the Scientific Revolution, ed. Gad Freudenthal and Peter McLaughlin, 1-40 (Dordrecht: Springer, 2009).

32 Bukharin, Science at the Cross Roads. Only Hessen's text has been reprinted in a stand-alone edition in Sydney 1946. For an analysis of the various editions of the text cf. Gerardo Ienna and Giulia Rispoli "Boris Hessen al bivio fra scienza e ideologia," in Boris Hessen, Le radici sociali ed economiche della meccanica di Newton, 39-41.

33 Jean François Braunstein, L’histoire des sciences (Paris : Vrin 2008); Jerôme Lamy and Arnaud SaintMartin, "La sociologie historique des sciences et des techniques. Essai de généalogie conceptuelle et d'histoire configurationnelle," Revue d'histoire des sciences 68, no. 1 (2015): 175-214.
} 
structure on the sphere of intellectual production. ${ }^{34}$ All these elements mutually concur to form a system in equilibrium, as we outlined above, where science, technology, and society reinforce each other.

The rhetoric of the scientific genius sent by God or appearing from nowhere is therefore deconstructed through the adoption of sociological tools of analysis capable of bringing to light a hidden side of the dynamics of scientific production and highlighting the communitarian structure of scientific activity.

It should also be emphasized that this historiographical model is not unrelated to a certain way of understanding the organization of scientific activity in contemporary times. The issues at stake in the science-at-the-crossroads debate therefore imply the discussion of two intimately connected aspects: on the one hand, the opposition between capitalist science and socialist science, and on the other hand, the opposition between internalist historiographic methodology and what has been called (not without discredit) externalist methodology. ${ }^{35}$ The approach proposed by the Soviet delegates inaugurated a method of inquiry that allows us to see both the effect of science on societal transformation and the impact of society on the production of scientific practices. The entanglement of these two aspects still represent a fundamental theoretical background that Marxism has provided in order to understand the most urgent problems of our contemporaneity.

Among the members of this visible college, Bernal and Needham were particularly prolific in their work to further the perspective of the Soviet delegates. ${ }^{36}$ Bernal was a strong supporter

\footnotetext{
${ }^{34}$ In the same period in France the historiographic current of Annales founded by Marc Bloch and Lucien Febvre emerged. This tradition has had relevant intersections with the debates in the history and philosophy of science, especially in the context of the French épistémologie historique (cf. Enrico Castelli Gattinara, Les inquiétudes de la raison: épistémologie et histoire en France dans l'entre-deux-guerres [Paris: Vrin 1988]). As pointed out by Maria Paula Diogo, "The Perfect Pair," authors gathered around the journal Annales have contributed in various ways to the history of science and techniques. These authors have proposed an approach based on the rejection of an event-based narrative (histoire événementielle). Their goal was rather to propose a historiographical model based on the concepts of total history, historyas-problem (histoire totale, and histoire-problème) aimed at proposing a long-term (longue durée) historical perspective on social and cultural phenomena. In analogy to what Hessen proposed in his speech in London, authors such as Braudel and Febvre devoted attention to the analysis of the material conditions of the emergence of technological forms as much as its effects on culture and society. This communion of purpose is also evident from the collaboration between the Bernalist authors Needham and Julian Huxley with Febvre in the context of the UNESCO project for the writing of the History of Scientific and Cultural Development of Mankind, cf. Maria Paula Diogo, "The Perfect Pair." See also Elena Aronova, Scientific History. Experiments in History and Politics from the Bolshevik Revolution to the End of the Cold War (Chicago: University of Chicago Press, 2021), 87-131.

${ }^{35}$ Wolf Schäfer, "Boris Hessen and the Politics of the Sociology of Science," Thesis Eleven 21, no. 1 (1988): 103-16, on 104.

${ }^{36}$ Steven Shapin, "Hessen thesis," in Dictionary of the History of Science, ed. William F. Bynum, 185-86 (London: Macmillan, 1982).
} 
of the Soviet model in its promotion of a harmonious development of society and science. ${ }^{37}$ In addition to his scientific studies about X-rays and molecular biology, Bernal authored several now classic texts, such as Engels and Science (1935); The Social Function of Science (1939); Marx and Science (1952); Science and Industry in the Nineteenth Century (1953); his monumental work in three volumes, Science in History (1954); Emergence of Science (1971). Especially in his 1939 book, he tried to address the question—particularly important for Marxism—of science policy. In accordance with Bukharin's presentation at the London congress that focused on the relation between science and ideology, and theory and praxis, Bernal delineated a way to put scientific practice at the service of society.

In this regard, he clearly stated that the interest in dialectical materialism in the United Kingdom emerged from the congress of 1931. In fact, the Soviet delegation "showed what a wealth of new ideas and points of view for understanding the history, the social function, and the working of science could be and were being produced by the application to science of Marxist theory." ${ }^{38}$ In a footnote, he also added an explicit reference to the Hessen thesis: "Hessen-article on Newton- . . . was for England the starting point of a new evaluation of the history of science." ${ }^{39}$ In this context Science in History served as a perfect example of how to provide a Marxist interpretation of the history of science. This text by Bernal would later become a classical point of reference within this discipline and considered by many a masterpiece. ${ }^{40}$

At the same time, Joseph Needham was publishing his Chemical Embryology (in three volumes) in 1931. During the preparation of this book, he also had the possibility to meet Charles Singer, the president of the London congress. During the congress, Needham was particularly impressed by Boris Zavadovskij's talk. Indeed, Zavadovskij reached the same conclusions of Needham, even if the former was starting from the axioms of dialectical materialism. Nevertheless, Hessen's contribution played the most significant role in shaping Needham's

${ }^{37}$ Serge Guérout, "Présentation," in Les racines sociales et économiques des Principia des Newton, Boris Hessen, 1-67 (Paris: Vuibert, 2006).

${ }^{38}$ John D. Bernal, The social function of science (London: Rutledge, 1946), 393.

${ }^{39}$ Ibid., 406.

${ }^{40}$ In fact, in 1981, on the occasion of the fiftieth anniversary of the London congress, the journal Isis dedicated a special part of its third issue to the theme of Marxism and history of science in which Jerome Ravetz and Richard Westfall contrasted precisely in attributing a different meaning to Bernal's science in history for the history of the discipline, cf. Jerome Ravetz and Richard S. Westfall, "Marxism and the History of Science," Isis 72, no. 3 (1981): 393-405. Consider also that the Society for Social Studies of Science, one of the major institutions in the field of STS, has awarded the J. D. Bernal Prize every year since 1981 to a scholar who has distinguished himself or herself by making a significant contribution to the study of the social dimension of science. Among the winners of this prize are: Robert K. Merton, Thomas Kuhn, Joseph Needham, Joseph Ben-David, Bruno Latour, David Edge, David Bloor, Harry Collins, Barry Barnes, Donna Haraway, Steven Shapin, Michel Callon, Sheila Jasanoff, Donald MacKenzie, Steve Woolgar, and Karin Knorr Cetina. 
thought. In his History of Embryology (1934) — a revised version of his text from 1931Needham wrote, "further historical research will enable us to do for the great embryologists what has been so well done by Hessen for Isaac Newton." ${ }^{41}$ In introducing the second edition of Science at the Cross Roads, he said, "This essay [by Hessen], with all its unsophisticated bluntness, had a great influence during the subsequent forty years, an influence still perhaps not yet exhausted." ${ }^{42}$ Also, in his later works-like the monumental seven-volume Science and Civilisation in China (published between 1954 and 2004) -Needham expressed his debt to the stimuli received by Bukharin, Hessen, and the other Soviet delegates.

Among those attending the conference was also the scientific journalist James Gerald Crowther. ${ }^{43} \mathrm{He}$ was particularly active in politics and closely associated with Hessen, with whom he maintained correspondence from 1931 until the death of the Russian physicist. ${ }^{44}$ Crowther was a very prolific scholar who represented a cardinal point in the evolution and dissemination of Marxist methodology in the history of science. By 1930, he had already published Science in Soviet Russia (his interest in this topic predated the congress). In The Social Relation of Science, Crowther also declared, "The movement, of which Hessen's essay was the most brilliant expression, transformed the history of science from a minor into a major subject." In particular, he declared that Hessen's perspective demonstrated how the history of science "was essential for the solution of contemporary social problems due to the unorganized growth of a technological society." ${ }^{35}$ As will be explained in the next paragraph, this broad UK leftist movement in science took the name of Bernalism in the following years (from the name of Bernal, its major authoritative scholar).

In the same context in which the Hessen theses were disseminated in the United Kingdom, one must also consider the economic historian, George Norman Clark. ${ }^{46}$ Despite being

${ }^{41}$ Gary Werskey, "Introduction," in Science at the Cross Roads, ed. Nikolai Bukharin, IX-XXIX (London: Frank Cass \& Co. Ltd., 1971), XXII.

${ }^{42}$ Joseph Needham, "Foreword," in Science at the Cross Roads, ed. Nikolai Bukharin, VII-X (London: Frank Cass \& Co. Ltd., 1971), VIII.

${ }^{43}$ Crowther was a correspondent for the Manchester Guardian and a secret member of the communist party. It was Crowther himself who revealed the real composition of the Russian delegation at least four weeks before the beginning of the conference.

${ }^{44}$ Christopher A. J. Chilvers, "The Dilemmas of Seditious Men: The Crowther-Hessen Correspondence in the 1930s," The British Journal for the History of Science 36, no. 4 (2003): 417-35.

${ }^{45}$ James Gerald Crowther, The Social Relations of Science (New York: The Macmillan Company, 1941), 617.

${ }^{46}$ Clark, who was the opening speaker of the first session of the London conference, was harshly criticized by the Soviet delegation. See Freudenthal and McLaughlin, "Classical Marxist Historiography of Science," 30. For the Russians, in fact, Clark's proposals (but also Hill's), went toward a new form of "the cult of heroes" of the history of science. From a Marxist point of view, it was considered necessary to break with individualistic and/or bourgeois philosophies of history, privileging instead studies that highlighted how the great scientists of the past had been influenced by the social and economic forces of their time. See Werskey, "Introduction," XXII. 
a detractor of Hessen's thesis, he clearly declared that Hessen's work represented "the best available statement" of the relation between the rise of modern science and the fall of the feudal economy. ${ }^{47}$ But Clark's reception of Hessen's work was not without criticism. In Science and Social Welfare in the Age of Newton from 1937, he specified that in order to explain the success of natural sciences in those centuries, there were other factors to be considered in addition to those indicated by Hessen. Together with the rise of the bourgeoisie, Clark underlined at least six other factors: the role played by religion, the concern for treating the sick, the desire to win wars, artistic creation, and the pursuit of pure knowledge. ${ }^{48}$ The third part of his book, titled Social and Economic Aspects of Science, is entirely dedicated to the discussion of Hessen's approach to the history of science. Various scholars have highlighted some of Clark's misunderstandings of Hessen's arguments (we will come back to this topic later) that were reproduced in the process of canonizing the author in the following years. From this point of view, Clark made a serious mistake in assuming that the study of the determinant social factors of scientific thought should consist mainly in dissecting a scientist's personal motivation. On the contrary, Hessen and the Marxist tradition have explicitly criticized this point as an individualistic tendency in philosophy. ${ }^{49}$ In particular, Clark argued that he would have used a "biographical" ${ }^{50}$ and "psychological" ${ }^{51}$ model in the history of science (i.e., precisely what the Russian authors criticized).

Although Clark's reading of Hessen's text is strongly critical and at times even caricatures, in our opinion it is necessary to consider that the English historian's objective is largely to overcome the "crude" approach of the Soviets by means of a series of additions that allow him to go beyond the strictly economic interpretation of Newton's work. Clark also knew Max Weber, whom he quotes explicitly in his text (a year before the publication of Merton's theses). ${ }^{52}$ Despite this, he recognized that the German author did not have a complete understanding of the relationship between religion, science, and technology. After having quoted The Protestant Ethic and the Spirit of Capitalism, he argued:

${ }^{47}$ George Norman Clark, Science and Social Welfare in Age of Newton (Oxford: Oxford University Press, 1937), 63.

${ }^{48}$ Guérout, "Présentation," 37; Clark, Science and Social Welfare, 89.

${ }^{49}$ Freudenthal and McLaughlin, "Classical Marxist Historiography of Science," 30.

${ }^{50}$ Clark, Science and Social Welfare, 86.

51 Ibid., 87.

52 Robert K. Merton, "Science, Technology and Society in Seventeenth Century England," Osiris 4 (1938): 360-632. See also Steven Shapin, "Understanding the Merton Thesis," Isis 79, no. 4 (1988): 594-605. 
It does not appear to me that this generalization is borne out by the facts. We have seen that Spain and Portugal were homes of the studies of navigation and medicine. In the sixteenth century Italy was the most fruitful field of science and technology; in the early seventeenth in France and the Catholic Netherlands had some great names; in the late seventeenth and eighteenth England and Holland had their turn. But there was a great deal more besides religion to account for this; many other elements of economic history were tending to the same result..$^{53}$

Throughout the 1930s, the Marxist approach to science was developed even beyond the British borders. Authoritative authors coming from very heterogeneous intellectual backgrounds had, in fact, already worked in this direction, so that a strong historiographic tradition began to consolidate in the West. ${ }^{54}$

\section{Bernalism as a Cultural Phenomenon and its relation to Soviet debates}

In the years following the London conference, the debates certainly did not end. During the 1930s, the so-called visible college was transformed into a progressively larger intellectual movement known as Bernalism. ${ }^{55}$ This name was motivated by the wide influence generated

\footnotetext{
53 Ibid, 85-6.

54 From the context of the Vienna Circle and Austro-Marxism, Edgar Zilsel developed an original interpretation of the birth of modern science as the resolution of a class conflict. Edgar Zilsel, The social origins of modern science (Dordrecht: Springer, 2013). Henryk Grossmann and Franz Borkenau, an economist and a sociologist, respectively, were both affiliated with the Institut für Sozialforschung (Institute for Social Research) in Frankfurt under Carl Grünberg's direction. These authors thus related in various ways to the nascent Frankfurt critical theory. Cf. Rick Kuhn, "Henryk Grossman and Critical Theory," History of the Human Sciences 29, no. 2 (2016): 42-59; Gad Freudenthal and Peter McLaughlin, ed., The social and economic roots of the scientific revolution: texts by Boris Hessen and Henryk Grossmann (Dordrecht: Springer, 2009); Valeria E. Russo, "Henryk Grossmann and Franz Borkenau A Bio-Bibliography," Science in Context 1, no. 1 (1987): 181-91; Rick Kuhn, "Introduction to Henryk Grossman's Critique of Franz Borkenau and Max Weber," Journal of Classical Sociology 6, no. 2 (2006): 57-100. Within this special issue and other articles, Peter D. Omodeo has instead analyzed the perspective elaborated by Gramsci. Pietro D. Omodeo, "La via gramsciana alla scienza," Historia Magistra 4 (2010): 53-68; Pietro D. Omodeo, "Egemonia e scienza: Temi gramsciani in epistemologia e storia della scienza," Gramsciana: Rivista internazionale di studi su Antonio Gramsci 2 (2016): 5986; Massimiliano Badino and Pietro D. Omodeo, Cultural hegemony in a scientific world: Gramscian concepts for the history of science (Leiden: Brill, 2020); Pietro D. Omodeo, "The Struggle for Objectivity: Gramsci's Historical-Political Vistas on Science against the Background of Lenin's Epistemology," HoSTJournal of History of Science and Technology 14, no. 2 (2020): 13-49. For a general perspective on these issues cf. Ienna and Rispoli, "Boris Hessen At The Crossroads of Science And Ideology."

55 For Bernalism's dissemination: Ravetz and Westfall, "Marxism and the History of Science"; Maurice Goldsmith and Alan Mackey, ed., The Science of Science (London: Pelican Books, 1966); Gary Werskey, "The Marxist Critique of Capitalist Science: A History in Three Movements?," Science as Culture 16, no. 4 (2007): 397-461; Aronova, Scientific History, 132-39.
} 
by The Social Function of Science in the British intellectual field, which allowed it to establish itself as a reference manifesto for Marxism in scientific debates. ${ }^{56}$

The wide influence of The Social Function of Science stemmed from Bernal's accurate prediction of the centrality that science would assume in the post-war politics that came to characterize the Cold War. ${ }^{57}$ As more and more countries drifted toward fascism or toward socialism in the 1930s, Bernal observed how science took on a different role in capitalist societies.

"Science is both affecting and being affected by the social changes of our times, but in order to make this awareness in any way effective, the intersection of the two needs to be analyzed far more closely than has yet been done." 58

Bernalism as a cultural phenomenon gradually expanded to involve both professional scientists engaged with the problem of the social responsibility of scientists and social scientists interested in studying science as a socio-cultural phenomenon. The sphere of intellectual debates of the 1930s that sprang from the 1931 London conference also had a longue durée effect over the following decades and fostered the Soviet reception of a wider range of intellectual debates.

Shortly before the conference, a new interdisciplinary field of research emerged in the Soviet Union. Naukovedenie (the science of science) stood at the crossroads of history, sociology, and epistemology. Russia's electrification plan, for example, was among the first objectives of naukovedenie, which became known as the study of the inherent nature of science and a general theory of scientific cognition. In 1926, Ivan A. Borichevsky described it as a study of the social purpose of science and its relations with other types of social creativity. According to Borichevsky, this area of knowledge did not yet exist, but it must. It was required by the very dignity of its object - the revolutionary power of exact knowledge. ${ }^{59}$ With this early description, naukovedenie can even be considered as a sociology of science ante litteram.

The main goal of the naukovedenie was to analyze science and technology as institutions, combining what we would now call organization and management of science and social studies of science. In Soviet Marxist terms, science is thus interpreted as a strategic productive force for the progress of society. This branch of research had a twofold task: on the one hand, to improve the performance of scientific researchers, and on the other, to understand the cognitive dimension of science using all relevant human and social sciences. Naukovedenie was thus configured as a field at the intersection of the two cultures, that is, between the

${ }^{56}$ Goldsmith and Mackay, The science of science, 9.

57 Werskey, "Introduction," XXIV.

58 Bernal, The Social Function of Science.

59 Ivan A. Borichevsky, "Naukovedenie kak tochnaya nauka," Vestink Znanija 12 (1926): 786; Yakov M. Rabkin, "Naukovedenie': The study of scientific research in the Soviet Union," Minerva 14 (1976): 61-78. 
humanities and social sciences (providing the method) and the natural sciences (representing the object). ${ }^{60}$ Apart from Borichevsky, the pioneering figures of naukovedenie in the 1920s include Bukharin and Vernadsky. In 1916, the latter had already recognized the need to address the problem of the organization of research and scientific work in Russia and the importance of creating a network of research institutes across the country and even at a global level. He argued that science is a global phenomenon, therefore in order to solve problems that pertain to the contemporary society, a concerted effort at the transnational level is required. Moreover, organization is fundamental when it comes to obtaining scientific achievements in a quick and "economic" way. ${ }^{61}$

Vernadsky worked to establish an institutional commission for the study of the history of knowledge at the Soviet Academy of Sciences. ${ }^{62}$ One of the objectives of the commission was to study nature in relation to the evolution of society, a project Bukharin mentioned in his presentation in London. The commission addressed the importance of developing the field of the humanities, paying exceptional attention to the history and philosophy of science and sociology. Vernadsky believed that scientific work could only be clarified in a historical context because only then it is possible to understand emergent phenomena. Moreover, he argued that the study of history had revealed the need for a reconstruction of science as transdisciplinary knowledge and as a global phenomenon. ${ }^{63}$ In this way, Vernadsky pointed out the problem of rationalization of science that was at the base of scientific and economic planning in the 1920s and 1930s.

In the 1910s and 1920s, an interdisciplinary intellectual field emerged in Poland as well, called naukoznawstwo (also translated as the science of science or logology). The main authors of the naukoznawstwo were Stanislaw Michalski and some representatives of the philosophical school of Lvov and Warsaw, such as Kazimierz Twardowski, Maria Ossowska, Stanislaw Ossowski, Taddeusz Kotarbinski, Kazimierz Ajdukiewicz, and Florian Znaniecki. ${ }^{64}$

${ }^{60}$ Elena Aronova, "The politics and contexts of Soviet science studies (Naukovedenie): Soviet philosophy of science at the crossroads," Stud East Eur Thought 63, no. 3 (2011): 175-202.

${ }^{61}$ Vladimir I. Vernadsky, Izbrannye trudy po istorii nauki (Moscow: Nauka, 1981).

${ }^{62}$ The first chair of the "History of Modern Scientific Thought," which discussed both the contributions of Soviet scientists and great classics such as Newton, was established in those years, and in 1927 the Institute of History of Science, as a part of the Natural Science Section of the Academy of Sciences, was taken over by Bukharin. The institute covered broad areas addressing the relationship between science, the arts, technology, scientific research methodology, and more.

${ }^{63}$ Vladimir I. Vernadsky, "O Zadachakh Komissii po izucheniu estestvennych proisvoditel'nich sil v dele organizacii specializirovannikh issledovatel'nikh istitutov," Voprosy istorii estestvoznaniya y techniki 1 (1999): 161-67.

${ }^{64}$ Michał Kokowski, "The Science of Science (naukoznawstwo) in Poland: Defending and Removing the Past in the Cold War," in Science Studies during the Cold War and Beyond, ed. Simone Turchetti and Elena Aronova, 149-76 (New York: Palgrave MacMillan, 2016), 150. 
Although the genesis of Polish and Soviet science of science studies were relatively independent from one another, their disciplinary histories intertwined as they developed. During the Stalin era in the Soviet Union, the whole scientific field of science suffered various forms of censorship and purges, abetted by Lysenkoism. Beside the most famous case, the Lysenko affair, in relation to which the geneticist Vavilov (one of the speakers at the 1931 conference) was sentenced to death, many of the authors who participated in the London Congress were publicly discredited or, in the worst cases, purged. ${ }^{65}$ The same fate impacted the institutionalization process of the naukovedenie and naukoznawstwo whose development came to an abrupt halt in the 1930s. ${ }^{66}$

For many years, the ideas of Bukharin, Hessen, Vavilov, and many others were banned in Soviet intellectual debates. Nevertheless, the kind of approach proposed by these authors and the naukovedenie and naukoznawstwo had already begun to circulate in Western countries. Because of these vicissitudes, Bernalism became, perhaps paradoxically so, the only survivor of the theories proposed by the Soviet delegates of London, which shortly in turn became a western version of the science of science. ${ }^{67}$

It was not until Stalin's death in 1953, and with the more moderate policies of his successor Nikita Khrushchev and especially those of Leonid Brezhnev beginning in the 1960s, that this type of study began to attract new attention in the Soviet Union. For this reason, it is only at the end of the 1950s and the beginning of the 1960s that there was a real institutionalization of the naukovedenie label, which hybridized with Polish naukoznawstwo and Western science policy. ${ }^{68}$ In fact, in 1965 the International Congress on the History of Science was held between Krakow and Warsaw with the participation of Soviet and Polish delegates, as well as scholars

\footnotetext{
${ }^{65}$ Needham, "Foreword," IX-X.

${ }^{66}$ In Poland, this type of study had suffered a major setback due to the double invasion of Nazi Germany and the USSR and the subsequent closure of many universities, foundations, and scientific associations. Cf. Kokowski, "The Science of Science (naukoznawstwo) in Poland," 151; Tadeusz Krauze, Zdislaw Kowalewski and Adam Podgórecki, "The Sociology of Science in Poland," in The Sociology of Science in Europe, ed. Robert K. Merton and Jerry Gaston, 193-223 (London-Amsterdam: Feffer \& Simons, 1977), 204; Loren R. Graham, Science in Russia and the Soviet Union: A short history (Cambridge: Cambridge University Press, 1993), 152.

${ }^{67}$ Cf. Goldsmith and Mackey, The Science of Science; Derek De Solla Price, Little Science, Big Science (New York: Columbia University Press). Also, the classical article by the Polish scholars Ossowska and Ossowski was translated and broadly disseminated in English by the journal Minerva: María Ossowska and Stanislaw Ossowski, “The science of science," Minerva 3, no. 1 (1964): 72-82.

68 It should be remembered that after the end of the war Poland was completely annexed to the countries under Soviet influence, which led to massive USSR control over academic posts in the nation's universities. In those years, for example, the texts of Marx, Engels, Lenin and Stalin were translated into Polish, as were the most important contributions of scientists from the Soviet regime such as Zhdanov, Lysenko, Vladimir Alexandrovic, etc. As for the science of science, the previous generation of scholars had largely been relieved of their institutional positions, leading to a forced alignment in this field of research with Soviet orthodoxy (cf. Kokowski, "The Science of Science (naukoznawstwo) in Poland," 152-55).
} 
from the Western Bloc. The conference was opened by Bernal and Mackay's plenary lecture entitled On the Roads to a Science of Science. This talk seems to have had an impact on the Soviets similar to that which Hessen's talk at the 1931 London conference had on the field of Anglophone scientific studies. ${ }^{69}$ Bernal and Mackey's text was quickly translated and published shortly thereafter in a popular Russian journal (Voprosy istorii estestvoznaniia i tekhniki).

The Russian reaction was immediate and, as early as 1966, Semjon R. Mikulinsky ${ }^{70}$ and Naum I. Rodny published an article entitled "Science as a Subject of Specialized Society" in which they defended a new stage of development and institutionalization of naukovedenie. ${ }^{71}$ In this text, the naukovedenie are described as having two components: one stemming from the history of science, the other aiming at the study of social and economic conditions and the psychological dimension of scientific thought. This is a justification for the turn of the Institute of the History of Science, founded by Vernadsky, toward the new field of the naukovedenie. ${ }^{72}$

Bernal's texts, which were translated, thus established themselves in the Soviet Union as a central reference in this academic field. More than 100 people attended the same conference, including Derek J. De Solla Price (USA), Gennady M. Dobrov (USSR), Michajlowicz Kedrov (USSR), René Taton (France), Ignacy Malecki (Poland). ${ }^{73}$ In particular, it is to the fortunate meeting between Dobrov himself (author of Science of Science: Introduction to General Science Policy Studies) and De Solla Price that part of the expansion of Soviet research in the field of infometry should be attributed. ${ }^{74}$ In 1966, thanks to the organization of a Soviet-Polish conference in Lvov, ${ }^{75}$ a real meeting between the naukovedenie and the naukoznawstwo took place. At that time, according to Dobrov, ${ }^{76}$ it would seem that the emergence of the label naukovedenie covered not only the science of science (and naukoznawstwo), but also the concept of Science Policy that was starting to emerge in those years in Europe. In fact, in 1971 the International Council for Science Policy Studies (ICSPS) was founded in Moscow, the first effective international institution in the field of Science and Technology Studies (STS). This international institution played a strategic role in linking Western STS with Soviet naukovedenie and social studies on science in some Third World countries. At the time of its

${ }^{69}$ Cf. E. M. Mirsky, "Science Studies in the USSR (History, Problems, Prospects)," Science Studies 2, no. 3 (1972): 281-94; cf. Rabkin, "Naukovedenie': The study of scientific research in the Soviet Union."

${ }^{70}$ Mikulinsky was the director of the Institute of History of Natural Sciences and Technology of the USSR Academy of Sciences.

${ }^{71}$ Mirsky, "Science Studies in the USSR," 283

${ }^{72}$ Rabkin, "Naukovedenie': The study of scientific research in the Soviet Union," 74.

${ }^{73}$ Kokowski, "The Science of Science (naukoznawstwo) in Poland," 160.

74 Linda Lubrano, Soviet Sociology of Science (Columbus-Ohio: American Association for the Advancement of Slavistic Studies, 1976), 9.

75 Cf. Gennady M. Dobrov, "The Sociology of Science in the URSS," The Sociology of Science in Europe, ed. Robert K. Merton and Jerry Gaston, 316-34 (London-Amsterdam, Feffer \& Simons, 1977), 316.

76 Dobrov, "The Sociology of Science in the URSS," 316-34. 
foundation, De Solla Price was appointed president and two vice presidents from both sides of the Iron Curtain were named: the Soviet Mikulinvski and the French Jean-Jacques Salomon. In this organization there were researchers from the Soviet bloc and others from the Western capitalist bloc at the same time. Among the most active members of the Soviet bloc in the ICSPS—engaged, obviously, with the naukovedenie and its variations - were Dobrov (USSR); Zdislaw Kowalewski, I. Malecki and Bohder Walentynowicz (Poland); Ladislav Tondl, R. Richta (Czechoslovakia); Nicola Stefanov (Bulgaria); Stefan Balan (Romania); Günter Kröber (GDR); and J. Farkas (Hungary). The spirit in which the ICSPS was born overcame the barriers of the cultural Cold War from the political-intellectual point of view related to technoscientific questions. This association represented, on the one hand, one of the principal vectors of diffusion of the naukovedenie and, on the other hand, one of the principal circuits by which some Soviets or Germans from the GDR had been able to enter into contact with the Western Science policy. ${ }^{77}$

The intuitions proposed by the Soviet delegates at the 1931 conference (later largely marginalized in the USSR) were re-proposed in an updated version by Bernal (and Bernalists like De Solla Price) who in the meantime had become intellectual points of reference-and privileged interlocutor-in the Soviet Union. In addition, the emergence of the new field of research, Science Policy, fostered an exchange of ideas between East and West. It is therefore a paradoxical dynamic of reverse circulation and of ideas and paradigms between the two sides of the Iron Curtain. ${ }^{78}$

The combined analysis of both the effects of science on social transformations and the impact of society in the production of scientific discourses still represents a fundamental theoretical contribution that Marxism has provided to understand the most urgent problems of our contemporary times. Following the legacy of the 1931 conference, science, and technology must therefore be investigated both by researching its economic roots-according to Hessen's expression-and by analyzing and imagining what the social function of science might be today—as Bernal would put it.

\footnotetext{
77 Aant Elzinga, "The rise and demise of the International Council for Science Policy Studies (ICSPS) as a Cold War bridging organization," Minerva 50, no. 3 (2012): 277-305; Gerardo Ienna, "Science and Technology Studies. Socio-epistemologia storica delle negoziazioni disciplinari." (PhD diss., Alma Mater Studiorum Università di Bologna, 2019), 189-96.

${ }^{78}$ For a general perspective on international circulation of ideas see Pierre Bourdieu, "Les conditions sociales de la circulation internationales des idée," Actes de la recherche in sciences sociales 145 (2002): 3-8; Gisèle Sapiro, Marco Santoro and Patrick Baert, eds, Ideas on the Move in the Social Sciences and Humanities: The International Circulation of Paradigms and Theorists (Dordrecht: Springer Nature, 2020). Egle Rindzevičiūte, The Power of Systems, How Policy Sciences opened up the Cold War World (Ithaca and London: Cornell University Press, 2016).
} 


\section{Conclusion: what we learned from the London congress (and the technosphere problem)}

When Paul Crutzen first introduced the Anthropocene notion in a meeting in Cuernavaca, Mexico, in 2000, he claimed that the Industrial Revolution indeed set in motion three concatenated processes: demographic growth, exploitation of natural resources, and environmental pollution. ${ }^{79}$ These processes are in turn associated with the mechanization of work, the transformation of energy made possible by the use of the steam engine, and the production and use of coal and iron. Crutzen's account clearly demonstrates how material, economic, and cultural development go hand in hand with growing environmental issues that with time brought about structural changes at the level of the Earth's functions and its geochemistry. The very controversial concept of the technosphere, namely an interconnected system of macroscale and micro-scale technologies supporting extractive economies, exploitation, and global trade illustrates the dynamics of global capitalism, reaching back into the past and stretching out into the future. ${ }^{80}$ Moreover, the technosphere is described as a complex system that operates outside human control, but it nevertheless imposes constraints on human behavior and collective decision. ${ }^{81}$ This concept reminds us of the longstanding problem of technological determinism, which stems from the belief that science and technology are neutral systems. ${ }^{82}$ The disconnection between society and nature seems to overlap with the disconnection that has often characterized the study of science as a phenomenon largely autonomous from its context, with the latter almost considered an element of noise and disturbance. Along these lines, the technosphere concept delocalizes and reduces human responsibility regardless of the changes that humanity has exerted on the Earth's surface and that have profoundly altered the general functioning of the biosphere. Most importantly, by denying human collective agency the technosphere concept obstructs any possibility of producing anti-systemic politics.

79 Paul Crutzen and Eugene Stoermer, "The Anthropocene," Global Change Newsletter 41 (2000): 17-8.

${ }^{80}$ Peter Haff, "Humans and technology in the Anthropocene: Six rules," The Anthropocene Review 1, no. 2 (2014): 126-36; Christoph Görg, Christina Plank, Dominik Wiedenhofer, Andreas Mayer, Melanie Pichler, Anke Schaffartzik and Fridolin Krausmann, "Scrutinizing the Great Acceleration: The Anthropocene and its analytic challenges for social-ecological transformations," The Anthropocene Review 7, no. 1 (2019): 1-20; Jürgen Renn, The Evolution of Knowledge, Rethinking Science for the Anthropocene (Princeton: Princeton University Press, 2020); see also Jürgen Renn, "The Evolution of Knowledge," HoST - Journal of History of Science and Technology 12 (2016): 1-22; Andreas Malm, Fossil Capital, the Rise of Steam Power and the Roots of Global Warming (London/New York: Verso book, 2016.)

${ }^{81}$ Jonathan Donges, Wolfgang Lucht, Finn Müller-Hansen and Will Steffen, "The technosphere in Earth System analysis: A co-evolutionary Perspective," The Anthropocene Review (2017): 1-11; Renn, The Evolution of Knowledge, 1-22.

${ }^{82}$ Wiebe E. Bijker, Thomas P. Hughes and Trevor Pinch, ed., The Social Construction of Technological Systems. New directions in the sociology and history of technology (Cambridge, Mass: The MIT Press, 2012). 
Fundamental contemporary issues that are also relevant to historians of science and technology, such as the Anthropocene and the technosphere reminds us how pressing it is nowadays to address, collect, and dwell upon historical attempts to conceptualize science and technology in relation to the material and cultural conditions of society, especially when it comes to economic development. The Anthropocene prompts us to investigate how cultural and scientific practices have shaped understanding and perceptions of nature and natural resources in relation to social changes and economic progress. The technosphere's own history is revealed through an analysis of our political and economic development. Economic and techno-scientific development complement each other. If economic development follows a trend of accumulation and consumption of natural resources, the technological apparatus will strengthen this economic system to maintain the privileges that have been obtained while reinforcing its stability at the same time.

The environmental crisis embodied by the Anthropocene notion reminds us of the importance of reconnecting the joint dynamics of political and social theories and action with the material conditions of technological development. This effort is important to gain the necessary knowledge to recalibrate social agency in a highly technologized world and move out of a logic of commodification of nature that prevails under neoliberalism.

In order to oppose the interpretation of the Earth in such a deterministic sense-as a superorganism above the sociosphere-it is necessary to re-materialize scientific and technological production and ground them in the social fabric. ${ }^{83}$ In this article, we have therefore revisited those attempts in the history of science and technologies that identified the need for promoting a new praxis and that account for a concerted analysis of the interdependencies of science, technology, and society. We deemed the 1931 London Congress as a good example for such a historical analysis. Although some of the presentations given in that context were naive and utterly propagandist, we consider this historic attempt to raise more systematic questions about the role of science in society to be incredibly relevant today, in a time in which social needs and the planet must find a new balance.

The 1931 London conference and its impact in the United Kingdom provides insight toward understanding how the reconnection of science and society has been thought about and elaborated upon in a moment of profound dissatisfaction for the role of science under capitalism, highlighting the need for reorienting the progress of humanity toward a new praxis. Past societies have produced technologies that enabled them to flourish and deploy the necessary means and intellectual skills that would allow them to maintain these privileges. Along these lines, Hessen showed how science has never been pure nor fully autonomous,

83 Renn, The Evolution of Knowledge; Johan Rockström, et al. "A safe operating space for humanity," Nature 461 (2009): 472-75. 
arguing that even Newton's mechanics were embedded in the social and material conditions of his time, a time that saw the end of the feudal system and the rise of a new social class. The idea that science can be abstract factually excludes a humanistic perspective from the equation and provides a misleading interpretation of (intellectual and material) history.

Reconnecting the joint dynamics of human society and nature is of the utmost importance in a time in which the metabolic rift imposed by capitalism is reinforcing once more the idea that planetary interconnected technological dynamics are independent of social agency. A way to pursue the reconnection of technological processes and social ecology invokes the study of the role that technology has played in cultural and economic development, its relationship with politics but also, as we sought to emphasize in this article, the study of the frictions and alliances that emerged from different visions of science and technology's role toward society.

The primacy of technology over society removes that fundamental dialectic Bukharin insisted upon in London, namely that praxis can be understood only in relation to theory and vice versa. Intellectual labor and physical labor are both forms of labor. Therefore, the dichotomy between theory as scientific ideas and praxis as concrete material context embedding the relations between forces of production is here overcome by a more systemic concept in which all elements shall ultimately find a balance.

The technosphere appears petrified in space and time as a sort of teleological organism with its own purpose. ${ }^{84}$ It would be a perfect epithet for Bernal's book The World, the Flesh and the Devil as the technosphere resembles a sort of giant, perverse, post-humanist organism that simultaneously reminds us of the urgency of recovering a return to a knowledge of both the natural sciences and of technologies that would help reinvest human energies and reorient them toward alternative future trajectories. ${ }^{85}$ Therefore, the intellectual synergies and debates the London conference sparked in the scientific community back then, still resonate today with the importance of addressing the reconnection of science and society to rethink forms of producing collective agency against capitalism.

\section{Acknowledgements}

This work would not have been possible without the help of a supportive group of friends and colleagues. We would like to thank Ana Simões and Antonio Sánchez for inviting us to contribute to this special issue, as well as Maria Paula Diogo and the two anonymous referees for their suggestions. We would also like to thank Pietro D. Omodeo and Massimiliano Badino

\footnotetext{
${ }^{84}$ Donges et al., "The technosphere in Earth System analysis."

${ }^{85}$ McKenzie Wark, "Introduction" in The World, the Flesh and the Devil: An Enquiry into the Future of the Three Enemies of the Rational Soul, ed. J.D. Bernal (London: Verso Book, 2018).
} 
for their comments on a previous version and the Max Planck Institute for the History of Science (Dep. I) in Berlin and the Ca' Foscari University of Venice for providing us with a stimulating environment for discussion.

This text is the result of collaborative work; however, Ienna is the author of the sections The Debates in the UK Stemming from the London Congress and Bernalism as a Cultural Phenomenon and its relation to Soviet debates and Rispoli of the paragraphs The Beginnings of the Social Study of Science in the 1930s and Conclusion: what we learned from the London congress (and the technosphere problem)

\section{Competing interests}

The authors have declared that no competing interests exist.

\section{Funding}

Ienna's contribution to this article is part of a project that has received funding from the European Union's Horizon 2020 Research and Innovation Programme (GA n. 725883 ERCEarlyModernCosmology).

This paper is part of the Special Issue "The Fabulous 1930s in the History of Science and Technology," eds. Ana Simóes and Antonio Sánchez, HoST - Journal of History of Science and Technology 14, no. 2 (2020), https:// sciendo.com/issue/HOST/14/2. It is being published in this issue (15.1) due to unforeseen circumstances that did not allow its publication earlier. 